\title{
Effect of halothane on metabolism of 5-hydroxytryptamine by rat lungs perfused in situ
}

\author{
Clyde A. WATKINS, Sue A. WARTELL and D. Eugene RANNELS \\ Departments of Physiology and Anesthesia, The Milton S. Hershey Medical Center, The Pennsylvania State \\ University, Hershey, PA 17033, U.S.A.
}

\section{(Received 4 A ugust 1982/Accepted 28 September 1982)}

\begin{abstract}
The effect of halothane (2-bromo-2-chloro-1,1,1-trifluoroethane) on the uptake of ${ }^{14} \mathrm{C}$-labelled 5-hydroxytryptamine $(5-\mathrm{HT})$ and its metabolism to 5-hydroxyindol3-ylacetic acid (5-HIAA) was investigated in rat lungs perfused in situ. The rate of accumulation of ${ }^{14} \mathrm{C}$-labelled 5-HIAA in the tissue, monitored as an index of 5-HT metabolism, was linear with time, displayed saturation kinetics and remained stable for at least $180 \mathrm{~min}$ of perfusion. Exposure of the lungs to halothane (4\%) for $60 \mathrm{~min}$ reversibly reduced production of 5-HIAA through an increase in the apparent $K_{\mathrm{m}}$ for metabolism of the amine from 1.45 to $3.52 \mu \mathrm{M}(P<0.001)$; the anaesthetic had no effect on the $V_{\max }$ of the process. The magnitude of the inhibition increased with time of exposure to the anaesthetic. Halothane exposure did not alter the distribution of $\left[{ }^{3} \mathrm{H}\right]$ sorbitol or $\left[{ }^{14} \mathrm{C}\right] 5-\mathrm{HT}$, pulmonary vascular resistance, levels of ATP or the kinetics of amino acid transport in the tissue. Inhibition of protein synthesis by cycloheximide did not mimic the effect of the anaesthetic. These observations, together with those made in lungs exposed to inhibitors of 5-HT uptake and metabolism, were consistent with a halothane-mediated inhibition of 5-HT uptake, which did not appear to involve non-specific changes in membrane permeability.
\end{abstract}

Structural and metabolic integrity of the pulmonary endothelium is required for normal lung function, including gas exchange, as well as the metabolic contributions of the lung to whole-body homoeostasis. Recent studies established the lung as an important site of metabolism of circulating drugs, peptides and vasoactive amines (Junod, 1977) and showed that these functions may be compromised by the variety of factors associated with lung injury (Seiler et al., 1976; Pennock et al., 1977; Fishman \& Renkin, 1979). For example, hypoxia reduced the activity of angiotension-converting enzyme in the hydrolysis of angiotensin I to angiotensin II both in intact lungs of anaesthetized dogs (Leuenberger et al., 1978; Stalcup et al., 1979a) and in cultured endothelial cells (Stalcup et al., 1979b). Although angiotensin-converting enzyme is not unique to the lung, its density in the pulmonary vasculature combined with the high volume of blood flow in the pulmonary bed makes the lung an important component in the regulation of blood pressure $(\mathrm{Ng}$ \& Vane, 1968; Gillis \& Roth, 1976; Roth \& Wiersma, 1979). Block \& Fisher $(1977 a, b, c)$ showed

Abbreviations used: 5-HT, 5-hydroxytryptamine; 5HIAA, 5-hydroxyindol-3-ylacetic acid. that clearance of 5-HT by perfused lungs removed from rats exposed to $100 \%$ oxygen was reduced; subsequent studies showed a similar depression of 5-HT uptake in cultured endothelial cells exposed to high oxygen tension (Block \& Stalcup, 1981).

Clinical observations (Pennock et al., 1977) suggested that lung injury during cardiopulmonary bypass led to modified lung function. Factors that might be implicated, in addition to hypoxia, include reduced or interrupted pulmonary flow, exposure to volatile anaesthetics or a combination of these conditions. However, the effects of these and other factors have not been investigated systematically. Metabolism of circulating noradrenaline was inhibited by halothane in lungs of intact dogs (Bakhle \& Block, 1976) and in perfused rabbit lungs (Naito \& Gillis, 1973); the latter effect was enhanced by $\mathrm{N}_{2} \mathrm{O}$. In addition, halothane inhibited the synthesis of lung proteins (Hammer \& Rannels, 1981; Wartell et al., 1981). However, the mechanism by which the anaesthetic may modify metabolism of lung cells, specifically that of endothelial cells, is unknown.

The present experiments assessed the effects of exposure of intact lungs to halothane on the uptake 
and metabolism of circulating 5-HT. The results indicated a progressive but reversible halothanemediated inhibition of 5-HT uptake at the cellular level, which did not appear to involve non-specific changes in membrane permeability.

\section{Materials and methods}

\section{Lung perfusion}

Lungs of male Sprague-Dawley rats (175-200g) obtained from Charles River Laboratories and allowed free access to food (Agway RMH 3000) and water were perfused as described previously (Watkins \& Rannels, 1980), except that the perfusion apparatus was modified from the previous design by inserting a Y-tube just before the pulmonary artery. This allowed perfusate containing $\left[2-{ }^{14} \mathrm{C}\right] 5-\mathrm{HT}$ to be introduced rapidly into the pulmonary vasculature from a second perfusate reservoir. After a preliminary period of equilibration of $10-180 \mathrm{~min}$, during which non-radioactive perfusate was recirculated, 5-HT metabolism was measured during a timed interval of single-pass perfusion with buffer containing radiolabelled 5-HT. Perfusion pressure was held at $20 \mathrm{~cm}$ of water under all experimental conditions.

The Krebs-Henseleit bicarbonate perfusion buffer used contained $5.6 \mathrm{~mm}$-glucose, 20 amino acids at the concentrations found in rat plasma (Watkins \& Rannels, 1980), 4.5\% (w/v) bovine serum albumin (fraction V; Pentex; Miles Laboratories) and 5-hydroxy $\left[2-{ }^{14} \mathrm{C}\right]$ tryptamine $\quad\left(\left[{ }^{14} \mathrm{C}\right] 5-\mathrm{HT} ; \quad 0.01-\right.$ $100 \mu \mathrm{M}$; New England Nuclear), as indicated. The perfusate was equilibrated with warmed $\left(37^{\circ} \mathrm{C}\right)$ humidified $\mathrm{O}_{2} / \mathrm{N}_{2} / \mathrm{CO}_{2}(4: 15: 1)$, containing halothane (2-bromo-2-chloro-1,1,1-trifluoroethane; Fluothane; Ayerst Laboratories Inc.) where indicated. Halothane was delivered to the gas mixture by using a Fluotec 3 vaporizer (Fraser-Sweatman Inc.); anaesthetic concentrations in the perfusion buffer were confirmed by using a Hewlett-Packard 5840-A gas chromatograph (Hewlett-Packard, Waltham, MA, U.S.A.), as detailed previously (Hammer \& Rannels, 1981). The same gas mixture was supplied to the ventilators.

\section{Cell culture}

Mixed lung cell cultures were obtained by enzymic digestion of minced rat lungs that had been cleared of blood by perfusion with $0.15 \mathrm{M}-\mathrm{NaCl}$ as detailed previously (Wartell et al., 1981). Cultures enriched in type II granular pneumocytes were prepared by a modification of the procedure of Mason et al. (1977) (S. A. Wartell, C. K. Nafe, C. A. Watkins \& D. E. Rannels, unpublished work). The cell suspension obtained by trypsin digestion was centrifuged $(20 \mathrm{~min}, 200 \mathrm{~g})$ over a discontinuous gradient of Ficoll in MEM-J; cells at the interface between the densities of 1.040 and 1.080 were collected and washed free of Ficoll. Contaminating macrophages were removed by adherence during two $15 \mathrm{~min}$ incubations in T75 tissue culture flasks.

For measurements of 5-HT metabolism, cell cultures were incubated in a temperature-controlled humidified Plexiglass box. A humidified gas phase of $\mathrm{O}_{2} / \mathrm{N}_{2} / \mathrm{CO}_{2}(4: 15: 1)$ was delivered to each plate through a perforated length of tygon tubing fitted to the inside of its lid. Halothane was delivered from a Fluotec vaporizer as described above. The experiment was initiated by replacing the medium with MEM-D containing $\left[{ }^{14} \mathrm{C}\right] 5-\mathrm{HT}$ ( 2 or $20 \mu \mathrm{M}$; sp. radioactivity $9.0 \mathrm{Ci} / \mathrm{mol}$ ), which was pre-equilibrated with the appropriate gas mixture ( \pm halothane). Samples of medium $(0.5 \mathrm{ml})$ taken from 1 to $120 \mathrm{~min}$ after addition of $\left[{ }^{14} \mathrm{C}\right] 5-\mathrm{HT}$ were assayed directly for content of $\left[{ }^{14} \mathrm{C}\right] 5$-HIAA by ion-exchange chromatography, as detailed below. Exposure to $4 \%$ halothane did not alter cell viability, as measured by exclusion of erythrocin B (control, $100 \%$; halothane treatment, $99.3 \%$ viable), nor did it change the number of cells per plate (Wartell et al., 1981).

\section{Measurement of 5-HT and 5-HIAA}

The content of 5-HT and 5-HIAA in tissue and perfusate samples was estimated by ion-exchange chromatography. After perfusion, the lungs were blotted, weighed and homogenized in $0.5 \mathrm{M}-\mathrm{HClO}_{4}$ using a Polytron homogenizer (Brinkman Instruments). Portions of perfusate $(2 \mathrm{ml})$ were deproteinized by addition of $\mathrm{HClO}_{4}$ to a final concentraion of $0.5 \mathrm{M}$. Acid-insoluble material was removed by centrifugation at $10000 \mathrm{~g}$ for $10 \mathrm{~min}$. The acid extracts were neutralized with $\mathrm{KOH}$, clarified by centrifugation and $1 \mathrm{ml}$ samples were applied to columns $(0.9 \mathrm{~cm} \times 2 \mathrm{~cm})$ of Bio-Rex 70 (Bio-Rad Laboratories) as described by Roth \& Gillis (1975). 5-HIAA was eluted from the columns with $4 \mathrm{ml}$ of water. 5 -HT was then eluted with $5 \mathrm{ml}$ of $0.25 \mathrm{M}-\mathrm{HCl}$. Radioactivity in the eluate fractions was determined by liquid-scintillation spectrometry using Formula 947 cocktail (New England Nuclear). Efficiency of counting was determined by an external standard ratios method. The amount of 5-HT and 5-HIAA in the samples was calculated on the basis of the specific radioactivity of $\left[2-{ }^{14} \mathrm{C}\right] 5-\mathrm{HT}$ added to the perfusate. T.l.c. (Hanson, 1966) of lung or perfusate extracts revealed no radioactive metabolites of 5-HT $(20 \mu \mathrm{M})$ other than 5-HIAA.

A series of studies was performed to examine the recovery of $\left[{ }^{14} \mathrm{C}\right] 5-\mathrm{HT}$ and its metabolite, $\left[{ }^{14} \mathrm{C}\right]-$ 5-HIAA, in $\mathrm{HClO}_{4}$ extracts of lung tissue and perfusate (Jonsson \& Lewander, 1970). When lungs were perfused for $2 \mathrm{~min}$ with buffer containing $\left[{ }^{14} \mathrm{C}\right] 5-\mathrm{HT}$ at concentrations ranging from 0.2 to 
$50.0 \mu \mathrm{M}$, than homogenized in $2 \mathrm{ml}$ of $\mathrm{HClO}_{4}$ $(0.5 \mathrm{M})$, an average of $59 \%$ of the radioactivity in the whole homogenate was recovered in the $10000 \mathrm{~g}$ supernatant of the acid extract (249 observations). Similar recovery was observed in acid extracts of perfusate samples. Recovery of 5-HT was not affected by the concentration of the amine in the perfusion buffer, by the length of time for which the lungs were perfused with buffer containing radioactive substrate, or by exposure of the lungs to halothane. Similar recoveries were observed when non-radioactive tissue or perfusate samples were homogenized directly with radioactive $5-\mathrm{HT}$ or 5-HIAA, suggesting that the material lost into the acid precipitate was representative of the metabolites in the supernatant fraction. No displacement of the bound material was observed when $1 \mathrm{mM}^{-}$ 5-HT was added to the $\mathrm{HClO}_{4}$ used for homogenization (control, $62 \pm 2 ;+1 \mathrm{~mm}-5-\mathrm{HT}, 57 \pm 3 \%$ recovery), when the homogenate volume was increased or when the $\mathrm{HClO}_{4}$ pellet was subjected to repeated acid washings followed by extraction with organic solvents, as described previously for purification of protein samples (Rannels et al., 1979). Thus, estimates of 5-HT and 5-HIAA were corrected for loss in the extraction procedure using recovery data obtained from individual tissue or perfusate samples.

\section{Other procedures}

Tissue content of ATP was determined enzymically by using $\mathrm{HClO}_{4}$ extracts of lungs frozen rapidly at liquid- $\mathrm{N}_{2}$ temperatures (Watkins \& Rannels, 1979). Extracellular space was estimated by using $\left[{ }^{3} \mathrm{H}\right]$ sorbitol; radioactive amino acid spaces were determined as detailed previously (Watkins \& Rannels, 1980). Significance of differences between means was determined by Student's $t$ test.

\section{Results}

To determine the feasibility of using the perfused rat lung preparation in situ for assessment of metabolism of circulating 5-HT, lungs were perfused for $10 \mathrm{~min}$ to allow equilibration and then were exposed to buffer containing $\left[{ }^{14} \mathrm{C}\right] 5-\mathrm{HT}$ for periods of 30-120s (Fig. 1). Analysis of tissue 5-HIAA content revealed that 5-HT metabolism was linear with time over the interval investigated and depended on substrate concentration. The rate of 5-HIAA production increased more than 2 -fold when perfusate 5-HT concentration was increased from 2 to $20 \mu \mathrm{M}$.

Initial rates of 5-HT metabolism were measured over $120 \mathrm{~s}$ intervals of perfusion at perfusate 5-HT concentrations ranging from 0.1 to $100 \mu \mathrm{M}$. In this range of substrate concentrations, 5-HIAA production displayed saturation kinetics (Fig. 2). After

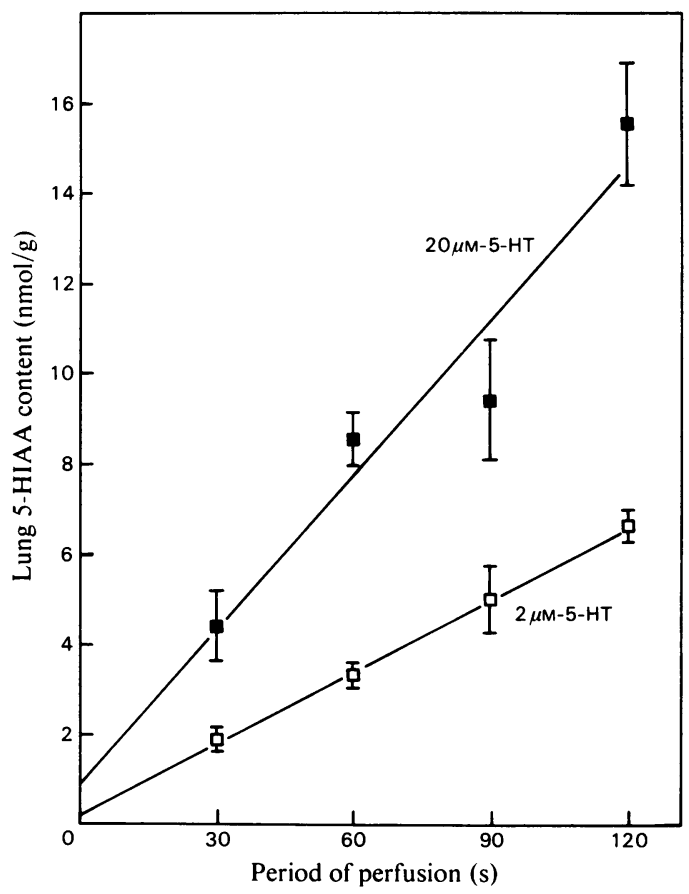

Fig. 1. Linearity of 5-HT metabolism in perfused lungs Lungs were perfused for a $10 \mathrm{~min}$ equilibration period as outlined in the Materials and methods section. Production of 5-HIAA from $\left[{ }^{14} \mathrm{C}\right] 5-\mathrm{HT}$ was measured over a subsequent interval of perfusion, as indicated. Data from lungs perfused with 2 and $20 \mu \mathrm{M}-5-\mathrm{HT}$ are represented by open and closed symbols respectively. Lung protein content was $118 \mathrm{mg} / \mathrm{g}$ of tissue; thus, $V_{\text {max }}$ is equal to $62.7 \mathrm{pmol} /$ min per $\mathrm{mg}$ of protein. Values represent means \pm S.E.M. (indicated by the bars) of three to 12 observations; the lines were drawn by least-squares linear regression.

periods of perfusion ranging from 30 to $120 \mathrm{~s}$, the $\left[{ }^{14} \mathrm{C}\right] 5-\mathrm{HT}$ space was equal to or less than that for $\left[{ }^{3} \mathrm{H}\right]$ sorbitol, suggesting that the $5-\mathrm{HT}$ within the tissue was primarily extracellular (results not shown). Furthermore, efflux of 5-HIAA into the perfusate could not be detected over the interval studied. These observations indicated that after its uptake from the pulmonary vasculature, 5-HT was rapidly metabolized by the lung to 5-HIAA and that the metabolic product remained in the tissue. Thus, in subsequent studies, 5-HIAA production was followed in samples of lung tissue as an index of 5-HT metabolism. When the kinetic data (Fig. 2) describing 5-HIAA production were replotted by the method of Hofstee, values of $1.66 \mu \mathrm{M}$ and $7.40 \mathrm{nmol} /$ $\mathrm{g}$ per min for the apparent $K_{\mathrm{m}}$ and $V_{\max }$ respectively were calculated.

The effects of inhibitors of monoamine oxidase 


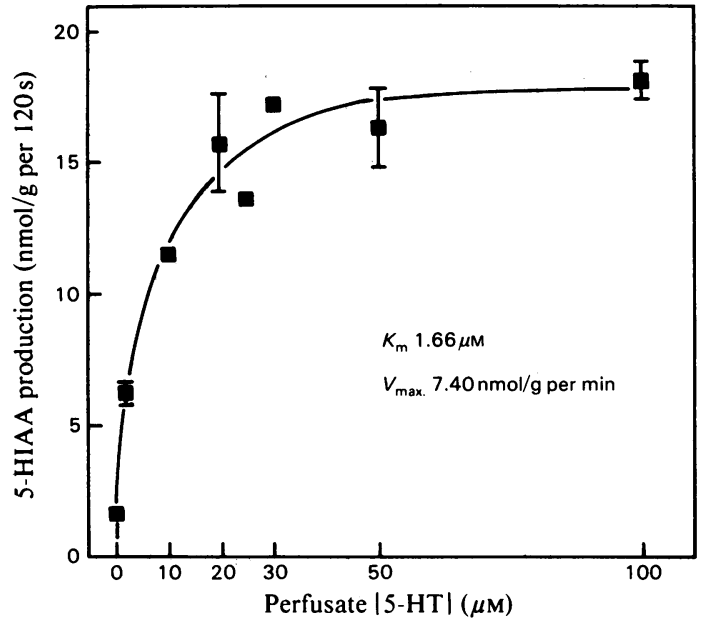

Fig. 2. Kinetics of 5-HT metabolism

After $10 \mathrm{~min}$ of preliminary perfusion, lungs were exposed for $120 \mathrm{~s}$ to perfusate containing $\left[{ }^{14} \mathrm{C}\right] 5-\mathrm{HT}$ at the concentrations indicated. The perfusate was discarded after a single pass through the pulmonary circulation. Tissue content of 5-HIAA was assayed as described in the Materials and methods section, and is shown as a function of perfusate 5-HT concentration. Results are means \pm S.E.M. (indicated by the bars); where bars are not shown, they did not extend beyond the symbol.

Table 1. Effects of imipramine and iproniazid on 5-HT metabolism

Lungs were perfused as outlined in the Materials and methods section and the legend to Fig. 1. Either imipramine $(20 \mu \mathrm{M})$ or iproniazid $(500 \mu \mathrm{M})$ was present during the $10 \mathrm{~min}$ period of equilibration, as well as during the subsequent $1 \mathrm{~min}$ flow-through perfusion, after which production of $\left[{ }^{14} \mathrm{C}\right] 5$-HIAA from $\left[{ }^{14} \mathrm{C}\right] 5-\mathrm{HT}(20 \mu \mathrm{M})$ was estimated. Recovery of radioactivity into the $\mathrm{HClO}_{4}$ extract supernatant was unaffected by the inhibitors: control, $61 \pm 2 \%$ (nine observations); imipramine, $66 \pm 2 \%$ (11); iproniazid, $67 \pm 2 \%$ (12). Results are means \pm S.E.M.of 11 to 14 observations

\begin{tabular}{lccc} 
& \multicolumn{3}{c}{ Lung content $(\mathrm{nmol} / \mathrm{g})$} \\
\cline { 2 - 4 } $\begin{array}{l}\text { Condition of } \\
\text { perfusion }\end{array}$ & 5 -HT & 5-HIAA & 5-HT + \\
$\begin{array}{lccc}\text { Control } \\
\text { + Imipramine }\end{array}$ & $2.44 \pm 0.48$ & $8.38 \pm 0.50$ & $10.85 \pm 0.78$ \\
+ Iproniazid & $13.07 \pm 1.34^{*}$ & $1.17 \pm 0.21^{*}$ & $2.93 \pm 0.23^{*}$ \\
& & $0.48 \pm 0.16^{*}$ & $13.80 \pm 1.30$ \\
$* P<0.01$ versus control. &
\end{tabular}

activity and 5-HT transport are shown in Table 1. Imipramine, a competitive inhibitor of 5-HT uptake substantially reduced 5-HIAA production compared with control tissues. Lung 5-HT content was
Table 2. Stability of 5-HT metabolism in perfused rat lungs

Lungs were perfused for the period indicated as outlined in the Materials and methods section and in the legend to Fig. 1. Production of 5-HIAA was then measured over a 2 min uptake period. Results represent means \pm S.E.M. for the numbers of observations shown in parentheses.

Period of
perfusion $(\mathrm{min})$
10
60
180

5-HIAA production ( $\mathrm{nmol} / \mathrm{g}$ per $\mathrm{min}$ )

$\begin{array}{cc}2 \mu \mathrm{M}-5-\mathrm{HT} & 20 \mu \mathrm{M}-5-\mathrm{HT} \\ 2.25 \pm 0.22(6) & 7.87 \pm 0.94(6) \\ 2.47 \pm 0.31(3) & 7.71 \pm 0.93(5) \\ 2.00 \pm 0.16(6) & 7.66 \pm 0.32(6)\end{array}$

unaffected, but total 5-HT uptake (5-HT + 5-HIAA) was reduced $72 \%$. Iproniazid, which blocks monoamine oxidase activity, also reduced 5-HIAA production but had no effect on total 5-HT uptake by the lung. These effects were consistent with previous reports that overall 5-HT uptake was not affected by the activity of monoamine oxidase and that the uptake process represented the rate-limiting step in the inactivation of this amine by the lung (Junod, 1972). Thus, the kinetic data above reflect uptake of 5-HT from perfusate.

Previous studies showed that the perfused lung preparation used in the present experiments was stable for at least $4 \mathrm{~h}$ (Watkins \& Rannels, 1979). Investigations of factors that may modify 5-HT metabolism in vitro require that amine metabolism remains stable during perfusion periods of similar duration. The data in Table 2 show that rates of 5-HIAA production measured over 2 min intervals were similar in lungs perfused for preliminary periods ranging from 10 to $180 \mathrm{~min}$. Similar observations were made in tissues exposed to 2 or $20 \mu \mathrm{M}-5-\mathrm{HT}$. These studies outlined conditions under which the effects of volatile anaesthetics and other agents on 5-HT metabolism could be investigated.

When lungs were exposed to halothane during $60 \mathrm{~min}$ of perfusion, 5-HIAA production remained linear over a 120 s interval. Fig. 3 shows Hofstee plots of kinetic data from control and halothaneexposed $(4 \% ; 60 \mathrm{~min})$ tissues obtained over a range of perfusate 5-HT concentrations from 0.01 to $100 \mu \mathrm{M}$. Kinetic parameters in this group of control tissues were similar to those shown in Fig. 2 . Halothane increased the apparent $K_{\mathrm{m}}$ for the substrate, as represented by the negative slope of the line, by 2.5 -fold, from 1.45 to $3.25 \mu \mathrm{M}(P<0.001)$. The anaesthetic did not affect the $V_{\text {max. }}$ of the system for 5-HT uptake and metabolism, as represented by the ordinate intercept.

As shown in Fig. 4, the ability of halothane to modify metabolism of 5-HT depended on the length 


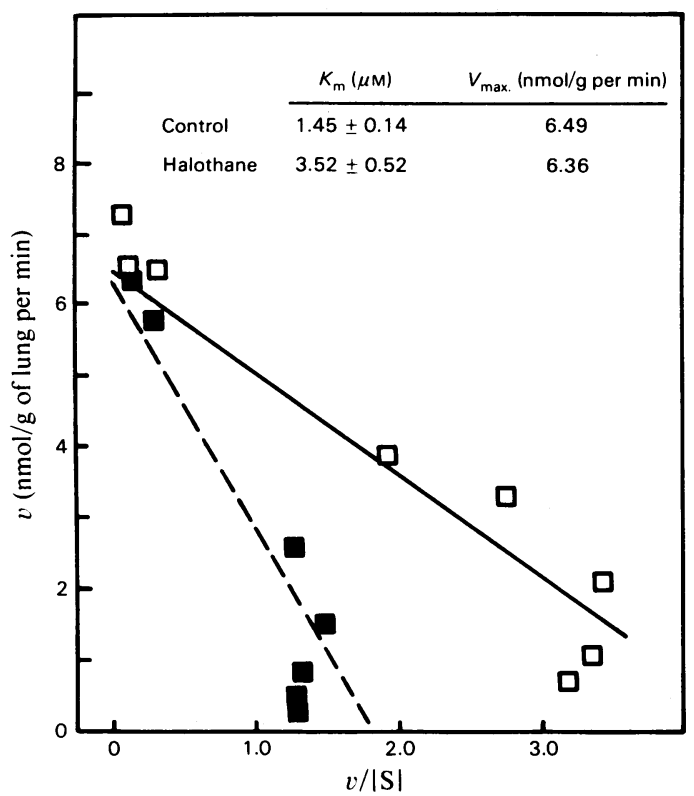

Fig. 3. Effect of halothane exposure on the kinetics of 5-HT metabolism by perfused rat lungs

Lungs were perfused as described in the Materials and methods section by recirculating the buffer for a preliminary period of $60 \mathrm{~min}$, during which some lungs were exposed to a gas mixture equilibrated with $4 \%$ halothane. Perfusion was then switched to a single-pass mode with the same buffer containing $\left[{ }^{14} \mathrm{Cl5}-\mathrm{HT}\right.$; the concentration of $5-\mathrm{HT}$ in the perfusion buffer was varied from 0.01 to $100.0 \mu \mathrm{M}$. Each point represents the mean of three to 11 observations. The lines were drawn using leastsquares linear regression based on individual observations. $\square$, Control lungs; $\square$, lungs exposed to halothane.

of time for which the lungs were exposed to the anaesthetic. Although $15 \mathrm{~min}$ exposure had little effect on 5-HIAA production (+halothane $=82 \%$ of control), a progressive increase in the inhibition was observed as exposure to halothane was continued. Metabolism of the amine was reduced to 60 and $46 \%$ of the control rate after 60 and $180 \mathrm{~min}$ of exposure respectively.

Halothane increased the $K_{\mathrm{m}}$ for 5-HT uptake without affecting the $V_{\text {max }}$; thus, the anaesthetic acted as a competitive inhibitor of 5-HT metabolism. In this context, the effect should be reversible. Direct examination of this point showed that 5 -HIAA production returned to $87 \pm 8 \%$ of control within $30 \mathrm{~min}$ after a $60 \mathrm{~min}$ exposure of the lungs to $4 \%$ halothane was stopped (halothane inhibition: $41 \pm 7 \%, P<0.001$ ). Tissues allowed $60 \mathrm{~min}$ for recovery metabolized $5-\mathrm{HT}$ at $94 \pm 7 \%$ of the control rate.

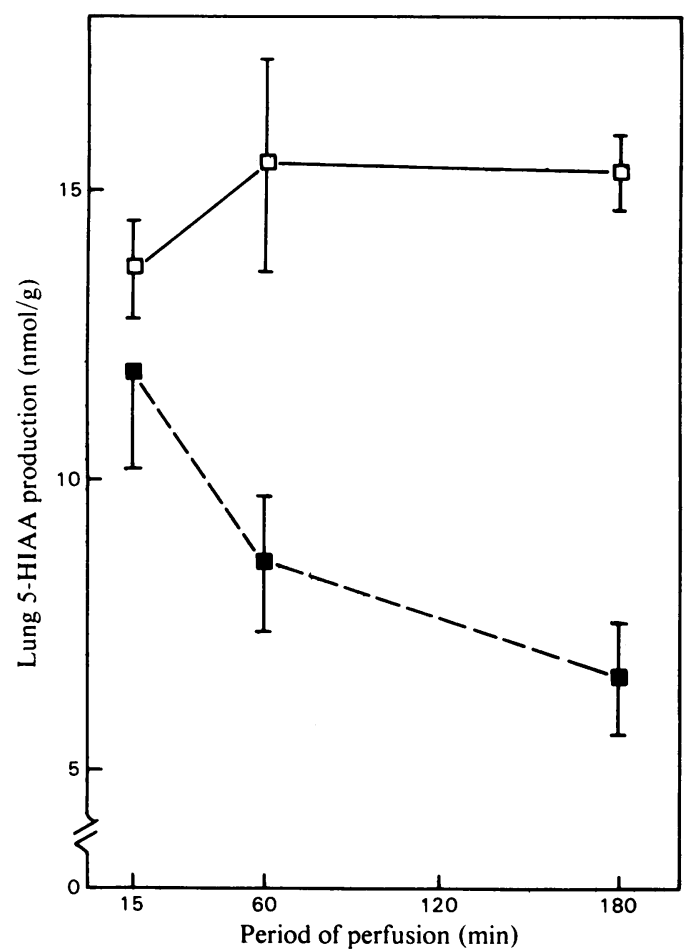

Fig. 4. Effect of perfusion time on the inhibition of 5-HT metabolism by halothane

Lungs were perfused as described in the legend to Fig. 3, except that the period of preliminary perfusion in the presence ( $\square$ ) or absence ( $\square$ ) of halothane was varied from 10 to $180 \mathrm{~min}$. Production of 5-HIAA was measured after $2 \mathrm{~min}$ of flow-through perfusion with buffer containing $\left[{ }^{14} \mathrm{C}\right]-$ 5-HT $(20 \mu \mathrm{M})$. Results are means \pm S.E.M. for five to seven observations.

Additional studies were intended to clarify the manner in which the effect of the anaesthetic was exerted. Anaesthetics, including halothane, are well known to alter vascular resistance (Price \& Dripps, 1975); such changes could alter metabolism of 5-HT indirectly by affecting a redistribution of pulmonary flow. Exposure of perfused lungs to halothane did not change overall vascular resistance (Wartell et al., 1981). When lungs were perfused at a constant pulmonary arterial pressure of $20 \mathrm{~cm}$ of water, pulmonary flow was $19 \pm 1$ and $20 \pm 1 \mathrm{ml} / \mathrm{min}$ per $100 \mathrm{~g}$ body weight in control and anaesthetic-treated lungs respectively. As further evidence that the effect of halothane was exerted at the cellular level, changes in 5-HT metabolism were sought in cultured lung cells exposed to the anaesthetic. Production of $\left[{ }^{14} \mathrm{C}\right] 5$-HIAA was monitored as a function of time in primary cultures of mixed lung cells. In halothane-exposed cultures, 5-HIAA pro- 


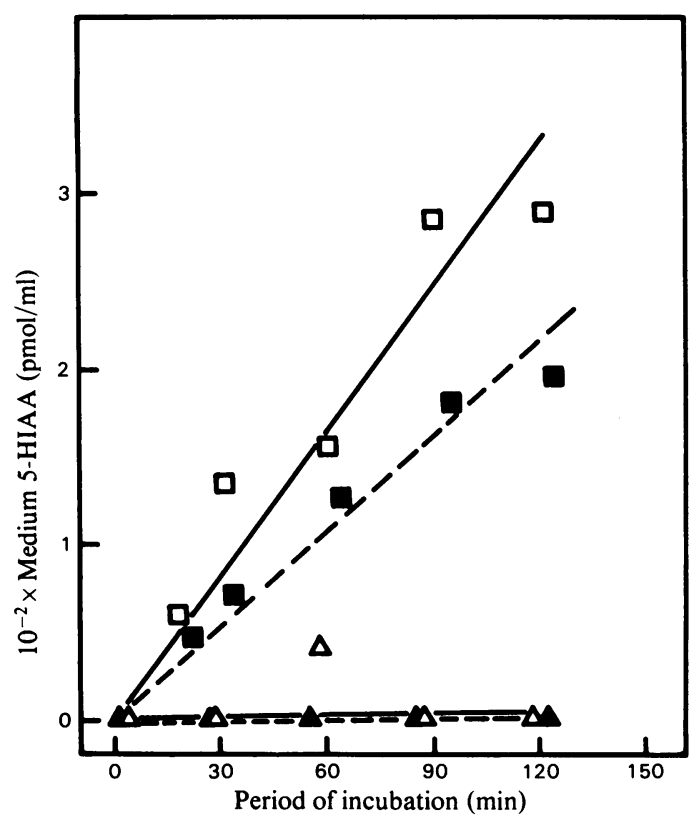

Fig. 5. Effect of halothane (4\%) on metabolism of 5-HT by cultured lung cells

Mixed lung cells ( $\square$ and $\square$ ) and type II alveolar pneumocytes ( $\Delta$ and $\boldsymbol{\Delta}$ ) were isolated and cultured as described in the Materials and methods section. Release of $\left[{ }^{14} \mathrm{C}\right] 5$-HIAA into the medium by cultures incubated in the presence of $20 \mu \mathrm{M}-5-\mathrm{HT}$ was measured after the times of incubation indicated; each point represents the mean of values obtained from three culture dishes. Lines representing the rate of 5-HIAA production in mixed cell cultures were drawn using least-squares linear regression and had correlation coefficients of 0.955 and 0.975 for data from control (-) and anaesthetic-exposed (----) cultures respectively. 5-HIAA produced in plates incubated in parallel, but without cells, was subtracted from each point. Cultures of mixed cells and type II pneumocytes contained 112 and $232 \mu \mathrm{g}$ of protein per plate respectively.

duction was reduced by $35 \%$, from 167 to $107 \mathrm{pmol} /$ $\mathrm{ml}$ per $\mathrm{h}$ at $20 \mu \mathrm{M}-5-\mathrm{HT}$ (Fig. 5), an inhibition similar in magnitude to that observed in perfused lungs. A $35 \%$ inhibition was also observed at $2 \mu \mathrm{M}-5$-HT ( 31 to $20 \mathrm{pmol} / \mathrm{ml}$ per $\mathrm{h}$ ). In parallel cultures of type II pneumocytes enriched to $77 \%$ purity, no metabolism of 5-HT was observed, in either the presence or absence of halothane (Fig. 5).

Exposure of the perfused lung preparation to $4 \%$ halothane vapour for $60 \mathrm{~min}$ did not appear to lead to irreversible damage to the tissue. In the presence of the anaesthetic, tissue levels of ATP were similar to those in unperfused or control lungs (unperfused,
$8.20 \pm 0.50 ;$ control perfused, $8.92 \pm 0.30$; plus halothane, $8.47 \pm 0.40 \mu \mathrm{mol}$ of ATP/g of dry lung). Furthermore, the inhibition of protein synthesis observed when perfused lungs or cultured lung cells were exposed to halothane (Hammer \& Rannels, 1981; Wartell et al., 1981) was rapidly and completely reversible. These observations, together with the lack of a change in the $V_{\text {max. }}$ for 5-HT metabolism and the reversibility of the inhibition of 5-HT metabolism suggested that the effects described above were not the result of cell death. However, the possibility that inhibition of protein synthesis might result in the present observations was considered. Lungs were perfused for 60 or $120 \mathrm{~min}$ with buffer containing cycloheximide at a concentration $(20 \mu \mathrm{M})$ known to inhibit synthesis of proteins by $95 \%$ (C. A. Watkins \& D. E. Rannels, unpublished work). No change in the metabolism of 5-HT was evident in lungs exposed to cycloheximide.

Halothane could inhibit 5-HT metabolism by interfering with the function of monoamine oxidase or by altering the distribution of 5-HT within the tissue. Inhibition of monoamine oxidase alone would increase tissue levels of 5-HT and reduce 5-HIAA production, as was observed in lungs exposed to iproniazid. The possibility that inhibition of monoamine oxidase led to accumulation of 5-HT within halothane-exposed lungs was examined by measuring the distribution of 5-HT in the extracellular and intracellular spaces of the tissue. Halothane had no effect on the extracellular space, estimated on the basis of the distribution of radioactive sorbitol. After $60 \mathrm{~min}$ of perfusion, $\left[{ }^{3} \mathrm{H}\right]$ sorbitol spaces were $0.29 \pm 0.01$ and $0.25 \pm 0.02 \mathrm{ml} / \mathrm{g}$ in control and halothane-exposed lungs respectively. Furthermore, the equilibration between perfusate and tissue 5-HT was unaffected in lungs exposed to halothane for $60 \mathrm{~min}$, then perfused for 30 to $120 \mathrm{~s}$ with buffer containing the amine. Together with the inhibitor studies presented above, these observations supported the conclusion that halothane modified 5-HT metabolism through inhibition of the transport process rather than of monoamine oxidase activity.

Current theories of the mechanism of action of anaesthetic hydrocarbons include perturbations of membrane structure and fluidity. Thus, the effect of halothane on 5-HT metabolism could reflect general alterations in membrane function. To test this possibility, rates of equilibration of two amino acids into lung tissue were investigated. The data in Fig. 6 describe the equilibration of $\left[{ }^{14} \mathrm{C}\right]$ phenylalanine into lung tissue; the amino acid space reached a constant value of $0.69 \mathrm{ml} / \mathrm{g}$ after $30 \mathrm{~min}$ and remained stable thereafter (Fig. 6a). Neither the time course of equilibration, nor the space at equilibrium was affected by halothane. Fig. $6(b)$ shows that when the data were expressed as a percentage of lung 


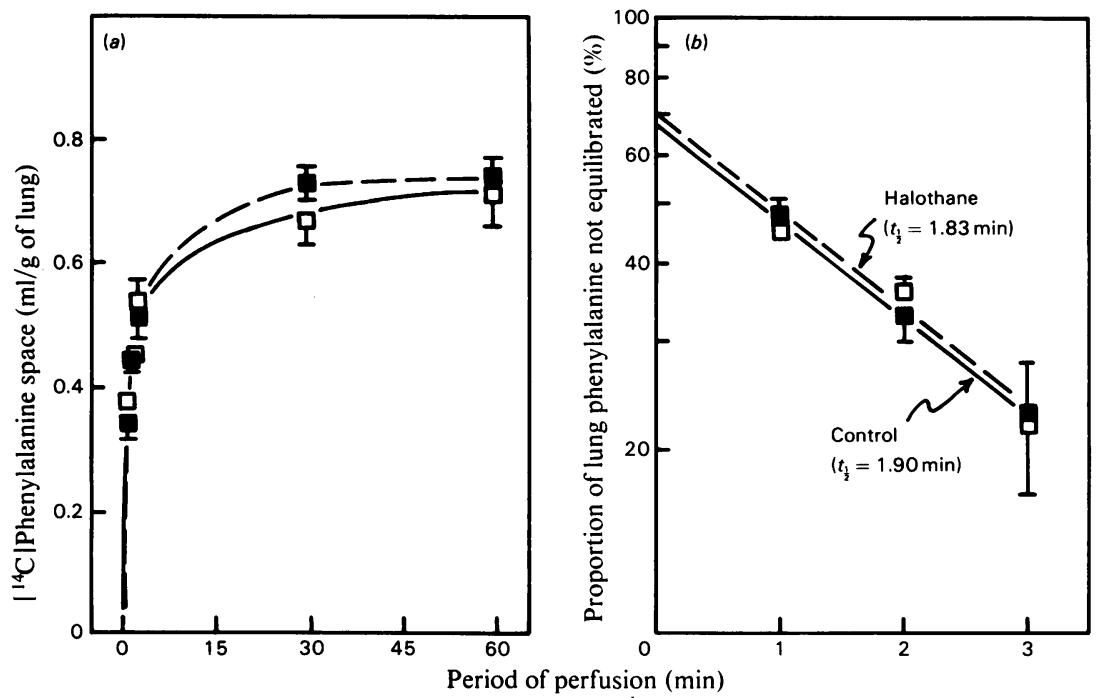

Fig. 6. Effect of halothane on entry of $\left[{ }^{14} \mathrm{C}\right]$ phenylalanine into perfused lungs

Lungs were perfused as described in the legend to Fig. 3 for a preliminary period of 30 min, with ( $\square----\square)$ or without ( $\square-\square$ ) halothane (4\%) exposure. Perfusion was then begun from a separate reservoir with buffer containing $\left[{ }^{14} \mathrm{C}\right]$ phenylalanine $(690 \mu \mathrm{M})$ and was continued for the period indicated, after which the $\left[{ }^{14} \mathrm{C}\right]-$ phenylalanine space was determined. The time course to an equilibrium space is shown in $(a)$. In $(b)$, spaces at 30 and $60 \mathrm{~min}$ were averaged to represent $100 \%$ equilibration; the ordinate intercept was accounted for by rapid equilibration of the amino acid in the extracellular space. Equilibration of intracellular phenylalanine with the perfusate was described by the equations $y=67 \mathrm{e}^{-0.36 t}$ and $y=70 \mathrm{e}^{-0.36 t}$ for control and anaesthetic-exposed lungs respectively, where $y$ represents the percentage of lung phenylalanine not equilibrated with the perfusate at time $t$ (min). Points represent means \pm S.E.M. (indicated by bars) of four to 11 observations; where a bar is not shown, it did not extend beyond the symbol.

phenylalanine not equilibrated with perfusate phenylalanine, the half-time of equilibration was unaffected by the anaesthetic. In an analogous experiment, lungs were pre-equilibrated with $\left[{ }^{3} \mathrm{H}\right]$ phenylalanine for $60 \mathrm{~min}$ with or without halothane present; the efflux of the amino acid was followed during subsequent perfusion without radioactive phenylalanine (Fig. 7). Halothane exposure had no effect on the rate of efflux of phenylalanine from the tissue, although metabolism of 5-HT was inhibited in the same lungs (results not shown).

Studies in other tissues suggested that phenylalanine was transported primarily on the ' $\mathrm{L}$-system' for amino acid transport, whereas proline was transported on the 'A-system', which exhibited properties similar to those of the transport system for 5-HT. Thus, an additional study of proline transport was completed. A $60 \mathrm{~min}$ exposure of perfused lungs to $4 \%$ halothane had no effect on the half-time of equilibration of lung and extracellular proline $\left(t_{t}\right.$ for control, $5.27 \mathrm{~min}$; for halothane exposure, $4.52 \mathrm{~min}$ ). These experiments indicated that the alterations in 5-HT transport and metabolism in halothane-exposed lungs did not reflect general changes in cellular permeability or membrane transport processes.

\section{Discussion}

Recent comparisons of 5-HT metabolism by liver and lung emphasized the role of both substrate concentration and blood flow in determining the relative importance of these tissues in clearance of the amine from the circulation (Wiersma \& Roth, 1980). However, many published investigations of 5-HT uptake and metabolism by intact lungs involved presentation of the amine at low concentration and at sub-physiological rates of pulmonary flow. As the perfusate was recirculated, disappearance of 5-HT or extraction of the amine relative to a marker of the vascular space could be determined. Although this approach provides the advantages that a time course of 5-HT uptake can be measured on a single lung preparation and that it can be applied in clinical determinations (Gillis et al., 1979), it also has several disadvantages. Low concentrations of substrate and/or rates of pulmonary flow are required to attain detectable and significant net uptake of the amine across the pulmonary vascular bed. Furthermore, the concentration of extracellular 5-HT decreases with time in recirculating systems and thus direct estimates of initial rates of uptake are compromised. As pulmonary flow is 


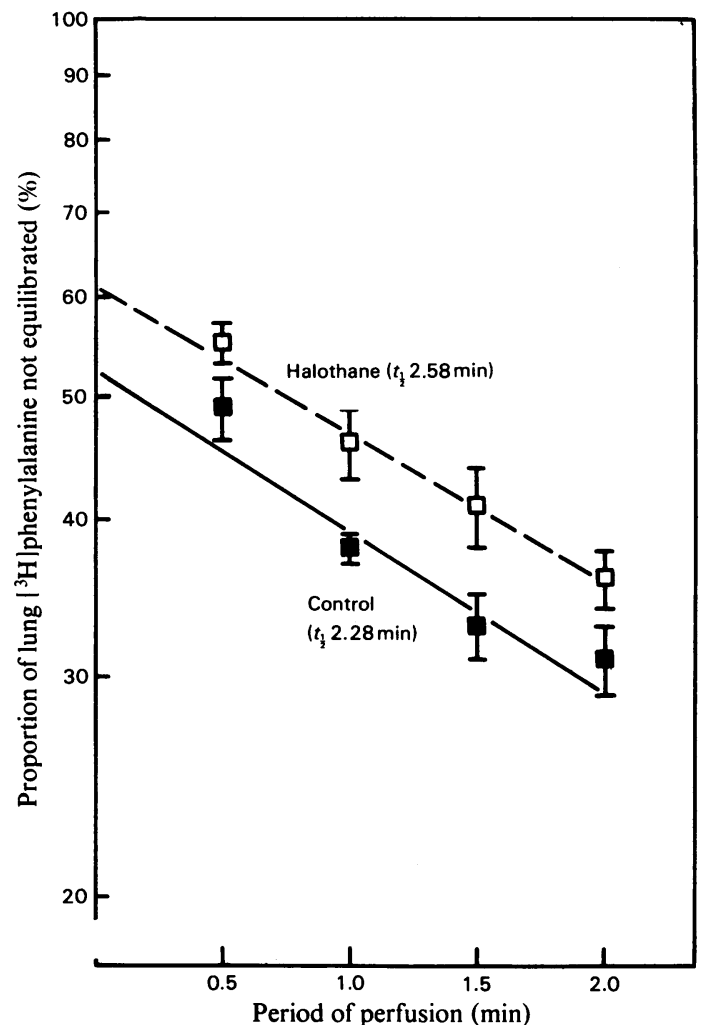

Fig. 7. Effects of halothane on efflux of $\left[{ }^{14} \mathrm{C}\right]$ phenylalanine from perfused lungs

Lungs were perfused as described in the Materials and methods section for $60 \mathrm{~min}$ with buffer containing $\left[{ }^{14} \mathrm{C}\right]$ phenylalanine $(690 \mu \mathrm{M} ; 0.15 \mathrm{Ci} / \mathrm{mol})$. Perfusion was then switched to a single-pass configuration using non-radioactive buffer and the $\left[{ }^{3} \mathrm{H}\right]$ phenylalanine space was estimated after the period indicated. The extent to which intracellular phenylalanine remained equilibrated with extracellular $\left[{ }^{3} \mathrm{H}\right]$ phenylalanine was described by the equations $y=54 \mathrm{e}^{-0.30 t}$ and $y=62 \mathrm{e}^{-0.30 t}$ in control $(\square)$ and halothane-exposed ( $\square$ ) lungs respectively, where $y$ represents the percentage of lung phenylalanine remaining equilibrated with radioactive phenylalanine in the perfusate at time $t(\mathrm{~min})$. Points are means \pm S.E.M. (indicated by the bars) of three to nine observations.

increased or as substrate concentration is raised, the arterial-venous difference in 5-HT decreases. Thus, reliable measurements of the disappearance of the amine from the vasculature cannot be made at physiological rates of pulmonary flow or at 5-HT concentrations approaching the $V_{\text {max. }}$ of the system. Finally, since 5-HIAA is retained within the tissue in short experiments, analysis of perfusate samples prevents simultaneous estimates of both 5-HT uptake and metabolism.

In the present studies, these disadvantages were avoided by analysis of tissue samples for levels of both 5-HT and 5-HIAA. This approach allows both flow and 5-HT concentration to be increased above the point where disappearance of the amine from the perfusate can be detected and it provides direct estimates of both 5-HT uptake and metabolism under more physiologically relevant flow conditions. 5-HT metabolism can be followed at high substrate concentrations, at rates near the $V_{\text {max }}$ of the system $(20 \mu \mathrm{M})$, as well as in the range of the apparent $K_{\mathrm{m}}$, so that the effects of agents that may affect lung injury on the 'capacity' and the 'affinity' respectively of the tissue for 5-HT metabolism can be evaluated.

When the lungs were presented with radioactive sorbitol and 5-HT under the same conditions, similar sorbitol and 5-HT spaces were observed. On the other hand, when monoamine oxidase was inhibited, tissue 5-HT increased to values substantially above those predicted by the sorbitol space. These observations suggest that in the absence of inhibitors, 5-HT is confined primarily to the extracellular space. On the other hand, 5-HIAA was produced within the cell and was not released to the perfusate in significant amounts during the 2 min studies reported here. Thus, analysis of tissue 5-HIAA provides a valid estimate of 5-HT metabolism.

The general characteristics of 5-HT metabolism in the present perfused lung preparation compare favourably with those reported elsewhere. Uptake of the amine was linear with time and initial rates of uptake remained stable throughout at least $180 \mathrm{~min}$ in vitro. Production of 5-HIAA was saturable with respect to perfusate concentration of 5-HT; values for the apparent $K_{\mathrm{m}}$ and $V_{\max }$. were similar to those observed by others (Hughes et al., 1969; Junod, 1972; Iwasawa et al., 1973; Nicholas et al., 1974; Pickett et al., 1975). Although a wide range of 'physiological' circulating 5-HT levels have been quoted in the literature (Rosenberg, 1964; Halevy et al., 1980), perhaps reflecting the extent of damage to platelets in the blood samples assayed, serum 5-HT is probably below the range of the $K_{\mathrm{m}}$ value observed in the present studies. Thus, the increased apparent $K_{\mathrm{m}}$ in lungs exposed to the halothane appears to be of relevance to metabolism of circulating 5-HT by the lungs of the intact animal.

Experiments using cultured lung cells provided strong evidence that the effect of halothane is exerted at the cellular level. Comparison of the rates of 5-HIAA production at 2 and $20 \mu \mathrm{M}-5-\mathrm{HT}$ (31 and $167 \mathrm{pmol} / \mathrm{ml}$ per $\mathrm{h}$ respectively) showed clearly that in the cell cultures, the kinetics of amine uptake differed from those observed in the intact organ. This precludes drawing of further conclusions from these observations. Additional kinetic studies should be carried out using cultured endothelial cells, rather than mixed cell populations. 
The inactivation of 5-HT involves cellular uptake by an $\mathrm{Na}^{+}$-dependent transport system and subsequent intracellular metabolism by monoamine oxidase (Junod, 1972; Nicholas et al., 1974). Production of 5-HIAA thus represents the combined activities of these processes. In the lungs, transport of the amine appeared to be rate-limiting for its metabolism and, in short experiments, inhibition of monoamine oxidase did not affect 5-HT uptake (Junod, 1972; Table 1). However, when the enzyme was inhibited, accumulation of unmetabolized 5-HT in the tissue was observed. For example, in perfused lungs iproniazid $(500 \mu \mathrm{M})$ inhibited 5-HIAA production by $95 \%$ and led to a 5 -fold increase in the tissue content of 5-HT. In contrast, 5-HT did not accumulate in halothaneexposed lungs. This suggested that the effect of the anaesthetic is exerted at the transport step; however, since transport remains rate-limiting to 5HIAA production, a less extensive concomitant inhibition of monoamine oxidase could not be ruled out. To verify this conclusion, direct investigations of the effect of halothane on transport of 5-HT by platelet-derived membrane vesicles (Rudnick, 1977) are under way.

In addition to its effect on the metabolism of circulating 5-HT, halothane rapidly and reversibly inhibited the synthesis of lung proteins (Wartell et al., 1981). In addition, a recent preliminary report suggested very rapid turnover of an endothelial cell membrane protein, angiotensin-converting enzyme (Ching et al., 1981). These studies opened the possibility that the progressive nature of the present inhibition could have reflected loss of activity of a rapidly-turning-over protein component of the transport system, which resulted from a decrease in its synthesis, with no change in its degradation. However, extensive inhibition of protein synthesis by cyclohexamide was without effect on 5-HT metabolism. These results suggest that the anaesthetic is likely to exert its effect more directly at the membrane level, perhaps through alterations in protein conformation (Eyring et al., 1973) or through changes in membrane fluidity (Trudell \& Cohen, 1975), which may be related to the mechanism of anaesthetic action. Thus, the effects of halothane on amino acid transport were investigated. These studies were intended to detect general effects of the anaesthetic on cellular permeability and on a transport process similar to that involved in 5-HT uptake. The observations made in these studies suggested that halothane did not generally affect membrane permeability in lung tissue, but interpretations with regard to specific effects on endothelial cells are more difficult. If it is assumed that these cells, which comprise about $30 \%$ of the total parenchymal lung cell mass (Crapo et al., 1980; Haies et al., 1981), are relatively sensitive to anaesthetic exposure, a small cell-type-specific reduction in amino acid transport could be lost against a background of unaffected cells. Again, further studies using purified endothelial cells in culture are required to fully define the specificity of the effect of halothane at the cellular or subcellular level.

This work was supported by grants HL-20344 and HL-27439 from the National Heart, Lung and Blood Institute of the National Institutes of Health. S. A. W. was a Postdoctoral Research Fellow of the Parker B. Francis Foundation, Hanover, NH, U.S.A. D. E. R. is the recipient of Research Career Development Award HL00294 from the National Heart, Lung and Blood Institute. We thank Mrs. Bonnie Merlino for typing this manuscript.

\section{References}

Bakhle, Y. S. \& Block, A. J. (1976) Clin. Sci. Mol. Med. 50, 87-90

Block, E. R. \& Fisher, A. B. (1977a) J. Appl. Physiol. 42, 33-38

Block, E. R. \& Fisher, A. B. (1977b) J. Appl. Physiol. 43, 254-257

Block, E. R. \& Fisher, A. B. (1977c) Chest 71 Suppl. 2, 289-291

Block, E. R. \& Stalcup, S. A. (1981) J. Appl. Physiol. 50, 1212-1219

Ching, S.-F., Hayes, L. W. \& Slakey, L. L. (1981) Fed. Proc. Fed. Am. Soc. Exp. Biol. 40, 1691 (abstr.)

Crapo, J. D., Barry, B. E., Foscue, H. A. \& Shelburne, J. (1980) Am. Rev. Resp. Dis. 122, 123-143

Eyring, H., Woodbury, J. W. \& D'Arrigo, J. S. (1973) Anesthesiology 38, 415-424

Fishman, A. P. \& Renkin, E. M. (eds.) (1979) Pulmonary Edema, American Physiological Society, Bethesda, MD

Gillis, C. N. \& Roth, J. A. (1976) Biochem. Pharmacol. 25, 2547-2553

Gillis, C. N., Cronau, L. H., Mandel, S. \& Hammond, G. L. (1979) J. Appl. Physiol. 46, 1178-1183

Haies, D. M., Gil, J. \& Weibel, E. R. (1981) Am. Rev. Resp. Dis. 123, 533-541

Halevy, S., Spector, S. \& Attura, B. M. (1980) Biochem. Med. 23, 236-238

Hammer, J. A. \& Rannels, D. E. (1981) Am. Rev. Resp. Dis. 124, 50-55

Hanson, A. (1966) Handb. Exp. Pharmacol. 19, 90-91

Hughes, J., Gillis, C. N. \& Bloom, F. E. (1969) J. Pharmacol. Exp. Ther. 169, 237-248

Iwasawa, Y., Gillis, C. N. \& Aghajanian, G. (1973) J. Pharmacol. Exp. Ther. 186, 488-507

Jonsson, J. \& Lewander, T. (1970) Acta Physiol. Scand. 78, 43-51

Junod, A. F. (1972) J. Pharmacol. Exp. Ther. 183, 341-355

Junod, A. F. (1977) Am. Rev. Resp. Dis. 115, 51-57

Leuenberger, P. J., Stalcup, S. A., Mellins, R. B., Greenbaum, L. M. \& Turino, G. M. (1978) Proc. Soc. Exp. Biol. Med. 158, 586-589 
Mason, R. J., Williams, M. C., Greenleaf, R. D. \& Clements, J. A. (1977) Am. Rev. Resp. Dis. 115, 1015-1026

Naito, H. \& Gillis, C. N. (1973) Anesthesiology 39, 575-580

Ng, K. K. F. \& Vane, J. R. (1968) Nature (London) 218 , $144-150$

Nicholas, T. E., Strum, J. M., Angelo, L. S. \& Junod, A. F. (1974) Circ. Res. 35, 670-680

Pennock, J. L., Pierce, W. S. \& Waldhausen, J. A. (1977) Surg. Gynecol. Obstet. 145, 917-927

Pickett, R. D., Anderson, M. W., Orton, T. C. \& Eling, T. E.(1975) J. Pharmacol. Exp. Ther. 194, 545-553

Price, H. L. \& Dripps, R. D. (1975) in The Pharmacological Basis of Therapeutics (Goodman, L. S. \& Gilman, A., eds.), 4th edn., pp. 79-92, McMillan, New York

Rannels, D. E., Sahms, R. H. \& Watkins, C. A. (1979) Am.J. Physiol. 236, E421-E428

Rosenberg, J. C. (1964) Ann. Surg. 160, 1062-1065

Roth, J. A. \& Gillis, C. N. (1975) J. Pharmacol. Exp. Ther. 194, 537-544
Roth, R. A. \& Wiersma, D. A. (1979) Clin. Pharmacokinet. 4, 355-367

Rudnick, G. (1977) J. Biol. Chem. 252, 2170-2174

Seiler, K.-U., Wasserman, O. \& Wensky, H. (1976) Clin. Exp. Pharmacol. Physiol. 3, 323-330

Stalcup, S. A., Lipset, J. S., Legant, P. M., Leuenberger, P. J. \& Mellins, R. B. (1979a) J. Appl. Physiol. 46, 227-234

Stalcup, S. A., Lipset, J. S., Woan, J.-M., Leuenberger, P. \& Mellins, R. B. (1979b) J. Clin. Invest. 63, 966976

Trudell, J. R. \& Cohen, E. N. (1975) Prog. Anesthesiol. 1, 315-321

Wartell, S. A., Christopherson, R., Watkins, C. A. \& Rannels, D. E. (1981) Mol. Pharmacol. 19, 520524

Watkins, C. A. \& Rannels, D. E. (1979) J. Appl. Physiol. 47, 325-329

Watkins, C. A. \& Rannels, D. E. (1980) Biochem. J. 188, 269-278

Wiersma, D. A. \& Roth, R. A. (1980) J. Pharmacol. Exp. Ther. 212, 97-102 